DOI

\title{
ОСНОВИ БІОЕТИКИ Й БІОБЕЗПЕКИ В СИСТЕМІ ВИЩОЇ МЕДИЧНОЇ ТА ФАРМАЦЕВТИЧНОЇ ОСВІТИ
}

\author{
I. Г. Кишкан, I. I. Заморський \\ Буковинський державний медичний університет
}

\section{FUNDAMENTALS OF BIOETHICS AND BIOSAFETY IN THE SYSTEM OF HIGHER AND PHARMACEUTICAL EDUCATION}

\author{
I. H. Kyshkan, I. I. Zamorskyi \\ Bukovynian State Medical University
}

\begin{abstract}
У статті висвітлено важливу роль навчальної дисципліни “Основи біоетики та біобезпеки” у формуванні біоетичного світогляду майбутніх лікарів і провізорів, їх відповідальності за результати своєї професійної діяльності з урахуванням біоетичних принципів, морального й біоетичного регулювання надання медичної допомоги населенню, а також для здійснення ефективної й безпечної фармакотерапії та вирішення питань біобезпеки при лікуванні пацієнтів. Відображено специфіку викладання основ біоетики та біобезпеки на кафедрі фармакології Буковинського державного медичного університету студентам III курсу залежно від їхньої спеціальності: “Лікувальна справа”, “Педіатрія”, “Медична психологія”, “Стоматологія” та “Фармація”.

The important role of the subject Fundamentals of Bioethics and Biosafety in the formation of bioethic world outlook of future doctors and pharmacists, their responsibility for the results of their professional activity concerning bioethical principles, moral and bioethic control of medical aid to the population as well as for effective and safe pharmacotherapy and solving the problems of biosafety at treatment of patients have been elucidated. The specific character of teaching the third course students Fundamentals of Bioethics and Biosafety at the Pharmacology Department of Bukovynian State Medical University depending on their specialty: “Therapeutics”, "Pediatrics”, “Medical Psycology”, “Stomatology” and "Pharmacy” has been interpreted.
\end{abstract}

Вступ. Вища медична і фармацевтична освіта в Україні на шляху до інтеграції з європейською спільнотою передбачає [1] підготовку грамотних, висококваліфікованих і гуманних фахівців, добре обізнаних з медициною чи фармацією, які, маючи грунтовні знання з біомедичної етики, сприятимуть дотриманню у своїй подальшій професійній діяльності норм Етичного кодексу лікаря і провізора з метою покращання здоров'я населення, якості та тривалості життя пацієнта. У сучасному суспільстві людина постійно стикається з проблемами безкомпромісної боротьби добра і зла, життя, хвороби і смерті, коли вирішується доля не лише окремого пацієнта, а й доля країни та всієї планети, зростає роль загальнолюдських цінностей, інтерес до “здорового способу життя”, виникають поняття “культура життя” та “культура спілкування”. Важливого значення для майбутнього медичного і фармацевтичного фахівця набуває уміння спілкуватись із пацієнтом, співчувати йому й лікувати добрим

(C) І. Г. Кишкан, I. І. Заморський та втішним словом. Адже професія лікаря чи провізора - це, насамперед покликання, і вимагає дотримання високих медико-етичних принципів та моральних цінностей в ім'я збереження життя і здоров'я людини. Це готовність завжди нести в душу пацієнта надію на одужання, слідуючи словам Авіценни “Aliis inserviendo ipse consumor” (“Служачи іншим, згораю сам”), допомагати й служити людині, постійно даруючи їй часточку своєї душі.

На сьогодні в медичній та фармацевтичній галузях простежується активний розвиток і запровадження новітніх медичних технологій та репродукції людини, трансплантології, генної інженерії й генної терапії, нових способів лікування захворювань за допомогою стовбурових клітин, становлення нанофармакології з використанням наноматеріалів при виготовленні ліків та їх можливого токсикологічного ризику, стрімке зростання арсеналу нових фармакотерапевтичних засобів, особливо з високою біологічною активністю [2, 3]. Поряд із сучасними досягненнями медичної та фармацевтичної науки важливого значення набу- 
вають біоетичні проблеми стосовно оцінювання новітніх медико-біологічних досягнень із точки зору визначення ступеня їх небезпеки для людини і всього людства, формування знань щодо законодавчих документів, які регламентують захист людини від небажаних наслідків впровадження нових біомедичних технологій. Актуальними постають питання поваги до життя людини, захисту прав людини та її гідності, безпечного застосування ліків [4], безпеки пацієнтів, біобезпеки й біозахисту людини і суспільства, відповідальності за збереження життя на планеті.

Про вагому значимість біоетики й біобезпеки у сучасному суспільстві свідчить проведення в Україні, починаючи з 2001 по 2013 роки, п’яти національних конгресів з біоетики, присвячених пошуку шляхів гармонізації сучасних досягнень біології, медицини та фармації з правами людини та ії гідністю. При проведенні цих конгресів активно обговорювались питання вдосконалення законодавства країни в галузі біоетики, організації роботи біоетичних комітетів, дотримання етичних норм і правил при проведенні доклінічних і клінічних наукових досліджень, соціальної відповідальності фармацевтичних компаній, впровадження сучасних біотехнологій та пошуку шляхів гуманізації медицини. Важливим завданням кожного форуму було сприяти поширенню викладання біоетики в навчальних закладах України.

Основна частина. Запровадження до навчальних планів підготовки фахівців напрямів "Медицина” та “Фармація” навчальної дисципліни “Основи біоетики та біобезпеки” є обгрунтованим і доцільним, оскільки сприяє формуванню морального й біоетичного регулювання надання медичної допомоги населенню, забезпеченню ефективної й безпечної фармакотерапії, засвоєнню основ належної клінічної практики при проведенні клінічних досліджень нових лікарських речовин і медичних технологій та вирішенню питань біобезпеки при лікуванні хворих. У Буковинському державному медичному університеті цей предмет викладається на кафедрі фармакології студентам III курсу медичних, стоматологічного та фармацевтичного факультетів з урахуванням специфіки майбутньої спеціальності [5] за кредитно-модульною системою. Робочим навчальним планом на вивчення основ біоетики та біобезпеки студентами спеціальностей “Лікувальна справа”, “Педіатрія” та “Стоматологія” передбачено 6 годин лекційних, 24 години практичних занять і 15 годин для самостійної роботи студентів (СРС) - разом 45 годин. Для студентів спеціальностей “Медична психологія” та “Фармація” (денна форма навчання) теж виділяється 45 годин, з яких 10 годин приходиться на лекційні та 20 годин на практичні заняття і 15 годин СРС. Із 2014-2015 навчального року цю дисципліну вперше вивчають студенти спеціальності “Фармація” заочної форми навчання, на викладання якої новим навчальним планом передбачено 54 години. Оскільки на заочній формі навчання більша частина матеріалу виноситься студентам на самостійне опрацювання, то із загальної кількості годин - 48 годин приходиться на СРС i лише 4 години на практичні та 2 години на лекційні заняття.

Лекції з основ біоетики та біобезпеки мають проблемний характер і передбачають розгляд нормативно-правового регулювання медичної i фармацевтичної галузі, законодавчих документів щодо питань біоетики та прав людини, функцій біоетичних комітетів, а також біоетичних основ проведення клінічних досліджень, професійної діяльності лікаря чи провізора. Для забезпечення якості знань студентів практичні заняття проводяться у вигляді дискусій, “круглих столів”, науково-практичних конференцій, під час яких обговорюються основні питання теми, підготовлені і розглянуті мультимедійні презентації та заслухані реферати. Методом ділової гри на заняттях відтворюються принципи етичного спілкування лікаря чи провізора $з$ пацієнтом та його родичами, 3 медичними та фармацевтичними працівниками. Зі студентами усіх спеціальностей на практичних заняттях розглядаються питання державного регулювання біомедичних втручань в організм людини на засадах біоетики, гідності та недоторканності людського життя від моменту його зачаття до природної смерті, біоетичні, правові та соціальні проблеми реанімації, болю, евтаназії, смерті, медикосоціальні питання аборту, генної інженерії, генної терапії та генетичних репродуктивних технологій. Жваву дискусію серед студентів викликають медико-етичні аспекти трансплантації та дарування органів, ксенотрансплантації з точки зору біоетики, соціальної вартості трансплантації, безпечного застосування наноматеріалів та ліків із високою біологічною активністю, а також питання здорового способу життя, соціальної етики та соціальної справедливості, питання ВІЛ-інфекції та СНІДу як біоетичні та соціальні проблеми [2, 3].

Зі студентами спеціальностей “Лікувальна справа”, “Педіатрія”, “Стоматологія” та “Медична пси- 
хологія” детально обговорюються біоетичні основи професійної діяльності лікаря, принцип правдивості, конфіденційності (лікарська таємниця) та поінформованої згоди на проведення досліджень і лікування, неінвазивних та інвазивних процедур. Із майбутніми педіатрами додатково розглядаються медико-етичні аспекти при лікуванні дітей різного віку, біоетичні, правові та соціальні проблеми вживання алкоголю, наркотиків та тютюнокуріння, їх шкідливість для організму дитини, заходи профілактики наркоманій та алкоголізму. Студентам спеціальності “Стоматологія” виділено окреме заняття, на якому підлягають обговоренню питання безпечного використання біополімерів та інших матеріалів для протезування і пломбування, що використовуються в стоматологічній практиці. Майбутнім медичним психологам більше уваги приділяється питанням психологічної підтримки хворого і його родини, створення довірливого контакту 3 пацієнтами та його близькими.

Студентам спеціальності “Фармація” денної та заочної форм навчання передбачено окрему лекцію стосовно стану сучасного фармацевтичного ринку з позицій біоетики та захисту прав споживача, медико-етичних та правових питань клінічних випробувань лікарських засобів, їх впровадження в клінічну практику, проблеми реклами лікарських препаратів, проведення генеричної заміни ліків та фармацевтичної опіки пацієнтів. Під час практичних занять з основ біоетики та біобезпеки розглядаються питання фармацевтичної біоетики та професійних вимог до майбутніх провізорів, медико-етичні аспекти запровадження формулярної системи, здійснення післяреєстраційного фармаконагляду.

Висновок. Вивчення студентами медичних i фармацевтичних факультетів основ біоетики та біобезпеки сприяє формуванню біоетичного світогляду майбутніх лікарів і провізорів, їх відповідальності за результати своєї професійної діяльності 3 урахуванням біоетичних принципів, здійсненню ефективної й безпечної фармакотерапії, належної підготовки фахівців для проведення біомедичних досліджень при запровадженні нових лікарських засобів і медичних технологій.

дії ліків / В. М. Бобирьов, Т. О. Дев’яткіна, О. М. Важнича // Фармакологія та лікарська токсикологія. - 2011. - № 1. - С. 64-66.

5. Заморський I. I. Особливості викладання основ біоетики та біобезпеки майбутнім лікарям та провізорам / I. I. Заморський, I. Г. Кишкан // Матеріали V Національного конгресу з біоетики з міжнародною участю (Київ, 23-25 верес. 2013 р.). - К., 2013. С. $159-160$. підручник / Галина Тере

4. Бобирьов В. М. Біоетичний підхід до призначення лікарських засобів і його роль у профілактиці побічної
Отримано 06.05.15 